\title{
Archivos Argentinos de Pediatría turns 90 years old
}

Before focusing on the $90^{\text {th }}$ anniversary of Archivos Argentinos de Pediatría, I would like to briefly review its history. On January $7^{\text {th }}$, 1867, the Charitable Society agreed to build a children's hospital in the city of Buenos Aires. After several delays, on April $9^{\text {th }}, 1875$, Hospital de Niños "San Luis Gonzaga" was opened. It was located at Victoria 1179 (today, Hipólito Yrigoyen 3420). In August of that same year, Ricardo Gutiérrez, M.D., returned to Argentina and became the hospital's manager. One year later, due to the hospital's small capacity, a new building was inaugurated at Arenales 1462. In 1886, Ricardo Gutiérrez asked the ladies from the Charitable Society to build a new, bigger hospital. After several problems and formalities, the building foundations were laid at Gallo 984/1016 (currently Gallo 1330) in March 1883. Towards the end of 1896, the building on Gallo Street opened. Unfortunately, Ricardo Gutiérrez, who had been the actual pioneer of the children's hospital for 20 years, was not able to attend because he passed away on August $26^{\text {th }}, 1896$. It is worth noting that the new and larger hospital wings were built under the commands of Christophersen, an architect who had won the gold medal at the Chicago exhibition. This was the first and largest children's hospital of Latin America. The first publication about pediatrics was the Revista del Hospital de Niños, launched in 1897 by Antonio Arraga, M.D., the hospital's manager.

In March 1905, Gregorio Araoz Alfaro, an M.D. from Buenos Aires, and Luis Morquio, an M.D. from Montevideo, founded the Archivos Latinoamericanos de Pediatria, the first ever pediatric journal of Latin America. Subsequently, Olinto de Oliveira, M.D., from Porto Alegre, and Fernandes Figureiras, M.D., from Rio de Janeiro, joined the journal.

The Archivos Argentinos de Pediatría were born in January 1930, after the Archivos Latinoamericanos de Pediatría had been published in conjunction with other countries for 25 years, until the editors from Uruguay, Brazil, and Argentina decided each country would publish its own journal. The first number of Archivos Argentinos de Pediatría was published in April 1930 and distributed on a monthly basis. Four years later, Brazil launched its Jornal de Pediatria.

The Sociedad Argentina de Pediatría (SAP) was presided over by Alfredo Casaubón, a leader in pediatrics nationwide and Head of the Service of Hospital de Niños de Buenos Aires. He delegated the management of Archivos Argentinos de Pediatría to María Teresa Vallino, an M.D. who was in charge of the Chair of Pediatrics and Newborn Infant Care at Unit VI of Hospital de Clínicas. Actually, back then, it was really uncommon for women to excel in medicine, so it was a great honor for Vallino, who was outstanding for her arduous and effective work in the early years of the publication, which continued until 1937. That year, Juan P. Garrahan, M.D. and great teacher, became the director of Archivos Argentinos de Pediatría and boosted its reputation until 1947, lasting for 10 years. Between 1947 and 1949, Florencio Escardó, a renowned physician and great author, managed the journal. He was followed by Alfredo Larguía, a great pediatrician and also an exceptional individual who in the early 1940s had been the editorial secretary, and who was the director of the Archivos Argentinos de Pediatría between 1949 and 1953. He was followed by Ignacio Díaz Bobillo, between 1953 and 1955; and then by Luis María Cucullu, between 1955 and 1957. Cucullu was a qualified pediatrician and was one of the first ones to study meningeal complications of tuberculosis in depth. Between 1957 and 1959, Carlos García Díaz became the director of the journal, who later became the manager of Hospital de Niños "Ricardo Gutiérrez." Between 1959 and 1961, José María Albores became the director, followed again by Alfredo Larguía between 1961 and 1965, who was the first twotime director of Archivos Argentinos de Pediatría. Then, Juan J. Murtagh, M.D., was appointed for the 1965-1969 period. Undoubtedly, he was an exemplary figure of the SAP and, among other things, his intense work enabled the purchase of the current SAP building on Coronel Díaz Street. He struggled a lot to get an amazing library, which was named after him in his honor. Félix O. Olivieri was the director between 1969 and 1971; Luis A. Márquez, between 1971 and 1972; and Juan Cruz Derqui, between 1972 and 1975. Under his direction, Archivos Argentinos de Pediatría was awarded the Antonio Rizzuto prize for the best scientific journal in 1973. Teodoro Puga took over for the 1975-1981 period, and he really improved the journal. For many years, he was one of the most prolific collaborators of 
the SAP. Puga was followed by Abel Bettinsoli between 1981 and 1982, and then by Héctor Mora, between 1982 and 1984. I was in charge in the 1984-1990 period, with the great help of Gerda Rhades, our amazing librarian for so many years. One of the qualitative aspects achieved by Archivos Argentinos de Pediatría in this period was that, in 1984, the journal was distributed exactly in the corresponding months. Another action was including reviewers to assess articles; this was undoubtedly a major step towards improving publications. Since 1987, there were several attempts to share Archivos Argentinos de Pediatría with Medline, the database of the United States National Library of Medicine (NLM). The first request for the indexation of our journal was sent in 1989, but it was rejected. Their assessors commented on all the aspects that needed improvement. In 1990, Ramón Exeni was appointed director (1990-1997) and a new attempt to be accepted in Medline was made in 1995, but rejection was the answer once again. Their report indicated that, although the journal had made improvements, these were not enough for acceptance. No other requests were made following this rejection. The journal director for the 1997-2000 period was Horacio Repetto, M.D., and for 2000-2006, Carlos Wharen. In 2006, I was appointed Director of the Publications and Library Council and Editor-in-chief of Archivos Argentinos de Pediatría. In the first months, Hebe Gonzalez Pena, M.D., and I started implementing many changes and thus brought many improvements to the journal. Towards the end of 2006, Norma Rossato, M.D., became the Assistant Editor, and with her help, we widened our Assistant Editor base. Among all, we set out on the arduous task of improving even more in order to be indexed in Medline. In July 2007, we received this encouraging message: "I am glad to announce that by Resolution 1071/07 of CONICET, Archivos Argentinos de Pediatría ISSN 0325-0075, run by you, has been included in the Core Set of Argentine Scientific Journals." This encouraged us to keep improving and, after several months, we managed to make substantial progress for the journal. In March 2008, we decided to contact the NLM to find out exactly what we needed to request the indexation. A few days later, we received an answer asking us to mail them the latest three numbers of Archivos Argentinos de Pediatría (October and December 2007 and February 2008), together with other various aspects. By mid-May, we received a letter telling us that the final assessment decision about indexation was going to be sent on July $1^{\text {st }}$. That day, we had our monthly editors meeting at the SAP building and, among other topics, we were expecting the answer about the indexation. By the end of the meeting, we received the letter. I put it in my pocket, but all the editors asked me to read it. To my great surprise, we had been accepted for admission to the Medline database, pointing out that the Archivos Argentinos de Pediatría was already indexed. We were astonished to see that the journal had been accepted without asking for corrections. In addition, we were surprised that the letter had arrived exactly on the specified date. Archivos Argentinos de Pediatría, together with Anales de Pediatria, by the Spanish Society of Pediatrics were the only two pediatrics journals in Spanish that were indexed in Medline.

Such milestone was very important and brought prestige to the SAP and increased the development of pediatric research in Argentina. To a great extent, we achieved this with the efforts of many editors that had improved the journal's quality in the 20 years before 2006 . Subsequently, improving the scientific quality of published material, its frequency of publication, and the excellence conditions required by this space has been an ongoing challenge for the entire pediatric community. In 2012, we started having our original articles, brief reports, special articles, updates, comments, and editorials translated into English, and also the original English articles we accepted translated into Spanish. Another important achievement of the past 10 years is that the articles of authors from various countries in Latin America, Europe and Asia were increasing. At present, approximately $40 \%$ of published articles come from other countries, an unprecedented fact for Archivos Argentinos de Pediatría.

I believe that this brief summary will help us know better about the history of Archivos Argentinos de Pediatría and thus we will celebrate the $90^{\text {th }}$ anniversary of our beloved journal with good wishes and affection.

\section{José María Ceriani Cernadas}

http:/ / dx.doi.org/10.5546/aap.2020.eng.2

To cite: Ceriani Cernadas JM. Archivos Argentinos de Pediatría turns 90 years old. Arch Argent Pediatr 2020;118(1):2-3. 